\title{
ESPAÇO IMAGEM
}

IMAGING SPACE

Responsável: Manoel Barros Bértolo

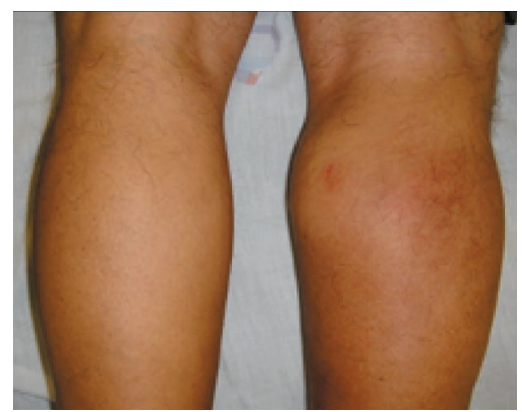

Figura A

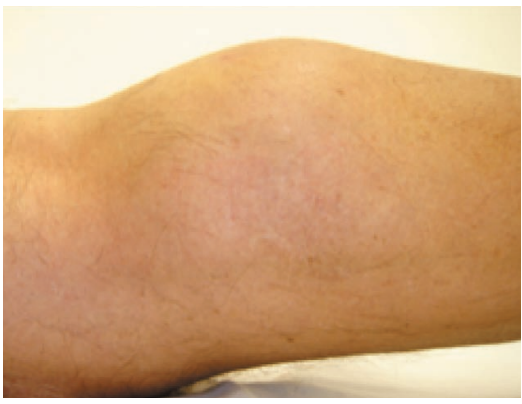

Figura B

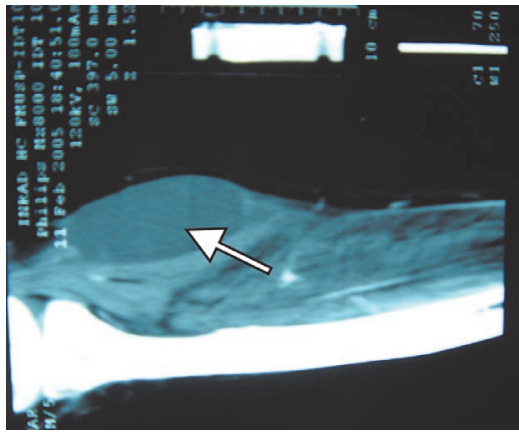

Figura C

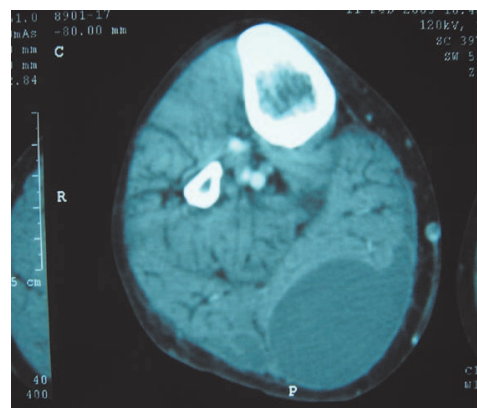

Figura D

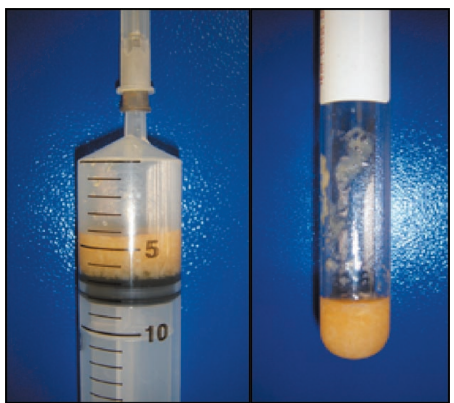

Figura $\mathrm{E}$

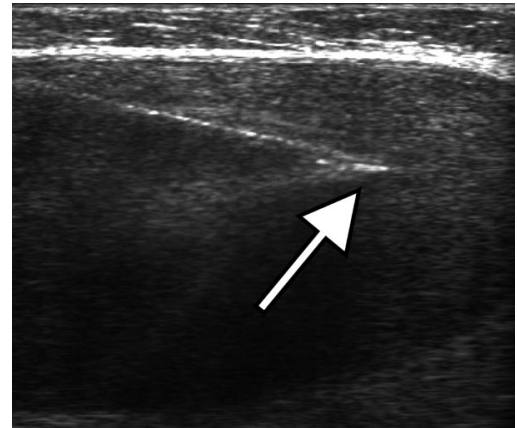

Figura $\mathrm{F}$

Paciente do sexo masculino, 56 anos, com queixa de inchaço progressivo na região posterior da perna direita. A: face posterior das pernas, com a presença de cisto de Baker à direita. B: perna direita em perfil. C: perna direita em perfil (ressonância magnética - RM). D: perna direita em corte transversal (RM). E: amostras colhidas do cisto de Baker desta perna, evidenciando produto exsudativo não-infeccioso. F: infiltração local, guiada por ultra-sonografia, de acetato de metilprednisolona.

Caso encaminhado por Samuel Katsuyuki Shinjo, Júlio César Bertacini de Moraes, Patrícia Martin, médicos residentes; Sandra Regina Miyoshi, médica preceptora, e Lais V. Lage, médica assistente do Serviço de Reumatologia do Hospital das Clínicas da Faculdade de Medicina da Universidade de São Paulo (USP). São Paulo, SP, Brasil. 